www.isarder.org

\title{
Akreditif Teyit Sigortası'nın Türk Finansal Kesiminde Uygulanması ve Muhtemel Etkileri
}

\author{
Letter of Credit Confirmation Insurance, The Implementation in Turkey \\ and Possible Effects
}

\section{Mehmet YEŞILILAPRAK}

Türk Eximbank

Sigorta ve Hazine Operasyon Daire Başkanı

İstanbul, Türkiye

orcid.org/0000-0001-8334-5191

myesilyaprak@eximbank.gov.tr

\begin{abstract}
Özet
Çalışmada, uluslararası ticaretin en önemli unsurlarından biri olarak değerlendirilen akreditiflere, çeşitli nedenlerle Türk bankalarınca teyit verilememesi problemine çözüm olabilecek "akreditif teyit sigortası" ürününün incelenmesi hedeflenmiştir. Bilindiği üzere, finansal kesimin en önemli aktörleri olan bankaların sıkça kullanılan ürünlerinden biri de akreditiftir. Akreditif, özellikle uluslararası ticaret işlemlerinde sıkça kullanılmaktadır. Ülkemizdeki bankaların yeterli yurtdışı banka muhabir ağına sahip olmadığı, limit tanıdıkları mevcut yurtdışı bankalara olan limitlerinin ise yetersiz kaldığı durumlarla sıkça karşılaşılmaktadır. Akreditif teyit sigortası ile; Türkiye'de yerleşik bankaların, bahse konu sigorta yapılmamış olsa teyit vermeyecekleri akreditiflerin sigortalanması yoluyla, bankaların bahse konu akreditiflere teyit vermesi sağlanmaktadır. Çalışmanın sonucunda, Türkiye'de herhangi bir kurum tarafından sunulmayan "akreditif teyit sigortası" ürününün pazara sunulması yoluyla ihracat hacminde artış sağlanacağı, teyit verilememesi sebebiyle gerçekleşemeyen önemli tutardaki ihracat potansiyelinin gerçeğe dönüştürülebileceği değerlendirilmiştir.
\end{abstract}

Anahtar kelimeler: Akreditif, teyitli akreditif, Eximbank, bankacılık, ihracat kredi sigortas1, Türk Eximbank, ihracat kredi (ve sigorta/garanti) kuruluşu.

\footnotetext{
Abstract

In this study, it is aimed to examine "letter of credit confirmation insurance product" which brings a matter to a solution for Turkish banks' difficulties to confirm letter of credits. As it is known, Letter of credit is one of the most frequent product used by financial institutions. Letter of credits are being used especially in international trade transactions. Banks operating in Turkey, often face difficulties such as having insufficient limits for the correspondent banks, having narrow correspondence network etc. Banks operating in Turkey, would be able to confirm letter of credits by means of letter of credit confirmation insurance; maybe they wouldn't be able to confirm these
} 
letter of credits if there is no insurance for their confirmed letter of credits. As a result of this study, it has been assessed that providing letter of credit confirmation insurance to the market which doesn't have such product yet would increase the volume of Turkey's exportation significantly and it could make possible to actualize an important potential export.

Keywords: Letter of credit, confirmed letter of credit, Eximbank, banking, export credit insurance, Turk Eximbank, export credit (and insurance/guarantee) agency.

\section{Giriş}

Son rakamlar, bazı dönemler dalgalanmalar olsa da, uluslararası ticaretin her geçen gün hacmini arttırdığını, ihracat ile ithalat rakamlarındaki yukarı yönlü ivme sektöre yeni aktörler katıldığını göstermektedir. Dünyaya en kapalı olduğunu iddia eden ülkeler, kalkınma yolunda globalleşmelerinin gerekli olduğunu farkına varmakta ve ihracata önem vermektedir.

Globalleşme ile birlikte, ünlü iletişim uzmanı Kanadalı Herbert Marshall McLuhan'ın bahsettiği “küresel köy”e dönüşmekte olan dünya getirdiği firsatlar nispetinde riskleri de beraberinde getirmektedir. Ticari, ekonomik, politik, sosyal alanlarda ortaya çıkabilecek bu riskler, ticaretin tarafları bağlamında; ihracatçıyı, ithalatçııı ve finansal kurumları farklı şekillerde etkilemektedir (Mcluhan, Powers, 1988).

İhracatçı; gönderdiği mallara ilişkin mal bedellerinin ödenmemesi, geç ödenmesi, malların kabul edilmemesi, mallarda kayıp veya hasar sebebiyle ödemenin eksik olması, malların gümrükte beklemesi veya ihraç ülkesine geri getirilmesinin ek maliyet yaratması gibi ticari risklerin yanında, döviz transferinin yasaklanması ya da kısıtlanması, mallara el konulması, malların millileştirilmesi, yasalar ve benzeri düzenlemelerle ödemelerin geciktirilmesi, boykot ve kur dalgalanmaları, savaş - iç isyan - ayaklanma gibi politik risklerle de karşılaşmaktadır.

İthalatçı tarafından bakıldığında satış sözleşmesine uygun hareket edilmemesinden kaynaklanan ticari risklerin söz konusu olabildiği görülmektedir. Mal bedelinin tamamen ya da kısmen ödenmesine karşın sipariş edilen malı alamamak, hatalı veya kalitesiz mal almak, malın geç gelmesi ve bu sebeple pazarın kaybedilmesi gibi riskleri bunlar arasında sayabiliriz. Ayrıca, yasalar ve benzeri uygulamalar nedeniyle mallara el konulması, millileştirilmesi, boykot ve kur dalgalanmaları gibi politik risklerin de ithalatçıyı etkilemesi kaçınılmaz olmaktadır.

Her ne kadar ticaretin "güven esasına dayalı bir ekonomik kavram” olduğu ifade edilse de, bunun ideal bir yapıyı temsil ettiğini söylemek yanlış olmayacaktır. Nitekim rekabetin yüksek seviyede olduğu günümüzde firmaların "pazarlama ve satış" birimlerinin önemi artmış, satış odaklı bir yapıya ulaşılmıştır. Bu çerçevede, firmalar kararlarını alırken belirli riskleri kabul etmek durumunda kalmaktadır. Uluslararası ticarette, tarafların bu sikıntılarını en aza indirebilmek adına uluslararası alanda kabul edilmiş ödeme şekilleri (ödemenin nasıl ve ne zaman yapılacağı) belirlenmiş ve bunlar ICC'nin kurallarıyla düzenlenmiştir. ICC kuralları ile düzenlenen ödeme şekillerinden biri olan akreditifli ödeme, masraflı bir yöntem olsa da, her iki taraf açısından çıkarları en fazla koruyan ödeme şeklidir. Böylece, ihracatçı ve ithalatçı arasındaki henüz olmayan güven ilişkisi akreditif yoluyla bankaların vasıtasıyla tesis edilebilecek, 
zamanla bu ticari ilişki "mal mukabili ödeme" gibi tamamen karşılıklı güvene dayanan bir ödeme şekline varabilecektir.

İhracatçı ve ithalatçı arasında belirlenen şartlara göre ödeme taahhüdünü içeren bir anlaşma olarak tanımlanabilen akreditif, ihracatçıya akreditif sözleşmesine uygun hareket ettiğine dair belgeleri, kendi bankası aracılığıyla ithalatçının bankasına sunduğu durumda, mal bedelini ithalatçının bankasından alabileceğinin güvencesini vermektedir. Nitekim, Türk Hukukunda da "akreditifin mal satın almış bir kimsenin, banka ile yapmış olduğu anlaşma üzerine o bankanın belli belgelerin satıcı tarafından ibrazı karşılığında, bu satıcıya satış parasının ödenmesini hedef tutan bir akit" olduğu 04.11.1964 tarihli ve T/E 962 K. 637 sayılı Yargitay kararında belirtilmektedir.

Akreditif ödeme şekli vasıtasıyla ihracatçı, alıcının ticari risklerini bertaraf etmektedir. Ancak akreditif, ithalatçının bankasının (amir banka) finansal yetersizliklerinin ve bu bankanın bulunduğu ülkenin ekonomik ve politik koşullarının yaratabileceği olumsuzlukları tam olarak ortadan kaldıramamaktadır. İhracatçı bu durumda, genellikle kendi topraklarında yerleşik başka bir bankanın ödeme yükümlülüğünü aldığg ' “teyitli akreditif” ödeme şeklini tercih etmektedir.

Teyitli akreditif ödeme şeklinde, teyit bankası ihracatçı ile bir kredi ilişkisi içine girerek, uygun vesaik karşılığında ihracatçıya ödeme yapma taahhüdü altına girmektedir. Burada da bazı riskler mevcut olup, bu risklerden en önemlisi teyit bankasının ihracatçıya ödemeyi yaptıktan sonra ilgili meblağı amir bankadan tahsil edememe riskidir. Bu noktada, teyit bankasının başvurabileceği yollardan biri akreditif teyit sigortası olabilecektir. Akreditif teyit sigortası; teyit bankasının, teyit ettiği akreditif tutarının ticari ve politik risklere karşı belli oranlarda - akreditife ilişkin çıkabilecek ihtilaflar dışında (rezerv) - teminat altına alınmasını içermektedir.

Çalışmada, akreditif teyit sigortasının tanımı, tarafları, genel iş akış süreci, alternatif enstrümanlara göre farklılıkları, dünyada ve Türkiye'deki kullanım alanı ve uygulama örnekleri incelenmiş ve bu sistemin ülkemizde uygulanmasının riskleri, fayda ve avantajları değerlendirilmiştir.

\section{Literatür Taraması}

Durukanoğlu tarafından, 18. yüzyılda kullanılmaya başladığı ifade edilen akreditifin ilk etapta tacirlerin seyahat yaparken hırsızlık ve çalınma riski nedeniyle yüksek miktarda para taşımak istememeleri ve ihtiyaçlarının karşılanmasına olanak sağlayacak şekilde yapacakları ticarete ilişkin parayı veya karşılığını bankaya yatırıp bankadan aldıkları yazı ile işlemlerini sonuçlandırmak istemeleri sonucundan kullanıma girdiği belirtilmiştir. 1840'l y yllardan itibaren de dış ticaret işlemlerinde kullanılmaya başlanmıştır (Durukanoğlu, 2008, ss. 128-129).

Polat tarafından belirtildiği gibi, riskli bir alan olan uluslararası ticaretin düzenlenmesinde Milletlerarası Ticaret Odası'nın önemli bir etkisi olmuş, bu çerçevede UCP ve ISBP kuralları oluşmuştur. Yine de uygulama farklı yorumların yapılması, kural metinlerinin farklı anlaşılması ve bilgi asimetrisi sebebiyle akreditiften sağlanan fayday1 azaltabilmektedir (Polat, 2008, ss. 209-222).

Akreditif ödeme şekliyle gerçekleştirilen ihracata yönelik sevkiyatların, ihracatçıların talebiyle sigortalanması yeni bir husus olmayıp Türk Eximbank tarafından 1989 yılından bu yana bu tür işlemler sigortalanmaktadır. Ancak çalışmamızda bahsi geçen Akreditif Teyit Sigortası'nda sigorta yaptıran taraf, ihracatçı değil akreditife teyit 
veren bankadır. Bu konuyla ilgili ne dünyada ne de ülkemiz özelinde bahse konu sigorta alt dalı ile ilgili yapılmış geniş kapsamlı bir çalışma bulunmamaktadır.

Türkçe en kapsamlı çalışma olarak Türk Eximbank uzmanlık tezleri arasında yer alan “Akreditif Teyit Sigortası ve Türk Eximbank'a Uygulanabilirliği” çalışması yer almaktadır. Bu çalışmada, "Türk Eximbank'ın ihracatçıların yeni ve riskli pazarlara girişini kolaylaştırmak ve mevcut pazarlardaki rekabet gücünü artırmak hedefleri göz önüne alındığında Akreditif Teyit Sigortası Programının bunları gerçekleştirmek doğrultusunda oldukça yararlı olacağı” ifade edilmektedir (Özelge, 2015, s. 35).

Türk Eximbank çağdaşı diğer uygulayıcı kuruluşlar, dünyada genellikle İhracat Kredi Kuruluşu (Export Credit Agency - ECA) adıyla anılmaktadır. Bu kuruluşlardan Akreditif Teyit Sigortası'nı uygulayanlardan başlıcaları Almanya Federal Hükümeti, DHAMAN (Çokuluslu kuruluş), EXIMBANK SR (Slovakya), EXIAR (Rusya), EFIC (Avustralya), EKN (İsveç), EKF (Danimarka), FINNVERA (Finlandiya), GIEK (Norveç), ICIEC (Çokuluslu kuruluş), OEKB (Avusturya), SACE (İtalya), SERV (İsviçre), UKEF (Birleşik Krallık) ve US EXIM (ABD)'dir.

\section{3. Ödeme Şekilleri ve Akreditif}

Uluslararası ticarette ödemeler dört şekilde gerçekleştirilmektedir; peşin ödeme, vesaik mukabili ödeme, mal mukabili ödeme ve akreditifli ödemedir. Ayrıca peşin ödeme dışındaki tüm ödeme şekillerinde kabul kredili ödeme adı verilen bir usul de kullanılabilmekte, bu durumda talep edilen belgelere ek olarak alıcı veya alıcının bankası üzerine bir poliçe keşide edilmektedir (Durukanoğlu, 2008, 121).

\subsection{Tarihsel Gelişimi}

Daha önce belirtildiği gibi ilk olarak 18. yüzyılda tacirlerin yanlarında para taşımak istememeleri amacıyla kullanılan akreditifler 19. yüzyılın ilk yarısında bugünkü anlamda kullanılmaya başlanmıştır (Durukanoğlu, 2008, 128-129).

Ticari ve teknolojik gelişmelerle birlikte akreditif de gelişmeye ve değişmeye devam etmektedir.

Her ne kadar ilk başlangıç zamanı kesin olmasa da Antik çağlarda akreditifin ilkel formlarının kullanıldığı ifade edilmektedir (Mugasha, 2003, s. 37). Avans ödemenin yerine geçmek üzere sırasıyla Mısır, Yunan ve Roma uygarlıklarında kullanıldıkları bilinmektedir.

Mısır'ın dünya medeniyetindeki öncülüğü bilindiğinden, ilk akreditif metninin bir çiviyazısı formatında Mısır'da bulunması şaşırtıcı olmamıştır (Mugasha, 2003, 38). Uluslararası ticaret ve finansa ilişkin ticari uygulamaların, finansal hesapların, poliçelerin, sözleşmelerin, akreditiflerin ve banka kredisinin; kısacası finansal sistemin temellerinin M.Ö. 3000'li yıllara ait kil tabletlerde bulunduğu görülmüştür (Ferguson, 1983, s. 381).

Yunan uygarlığında trapezitai adı verilen bankacılar, farklı madeni paraların bozdurulması işini başlatmıştı. Daha sonra işlerini genişleterek borç verenlerle borç alanlar arasında aracılık hizmeti veren bankacılar, sermaye hareketlerini yönlendirmeye başladılar. Ayrıca, bu tür aktivitelerinin dışında seyyahların yanlarında para taşımak istememeleri sebebiyle akreditifler düzenlemeye başlamışlardır (Mugasha, 2003, s. 39). 
Antik Roma'daki bankacılık sistemi, bolca ganimet elde edilmesi ve aşırı vergi sistemi sayesinde biriken devasa büyüklükteki parasal kaynağının farklı madeni para cinslerine çevrilmesi, uzun mesafelere para taşımanın zorlukları ve banka kredilerine olan talep esaslarından oluşmaktaydı. $\mathrm{O}$ dönemde, the receptum argentarri adı verilen işlem, modern akreditiflere benzemekteydi (Mugasha, 2003, s. 40).

\subsection{Tanımı}

Daha önce de ifade edildiği gibi, ihracatçı ve ithalatçı arasında belirlenen şartlara göre ödeme taahhüdünü içeren bir anlaşma olarak tanımlanabilen akreditifte temel belirleyiciler bankalar olmaktadır. Uygulamada her akreditifin ICC tarafından yürürlüğe konan UCP 600 kurallarına uygun olarak işlem gördüğü gözlemlenmektedir. İlgili vesaikin bankaya sunulması ile, görüldügünde veya vadeli olarak ödeme imkânı sunan akreditif; "banka garantisi" ve "ödeme" kombinasyonudur (Grath, 2008, s. 47). Akreditif, aşağıdaki yer alan iş akışı çerçevesinde işlemektedir.

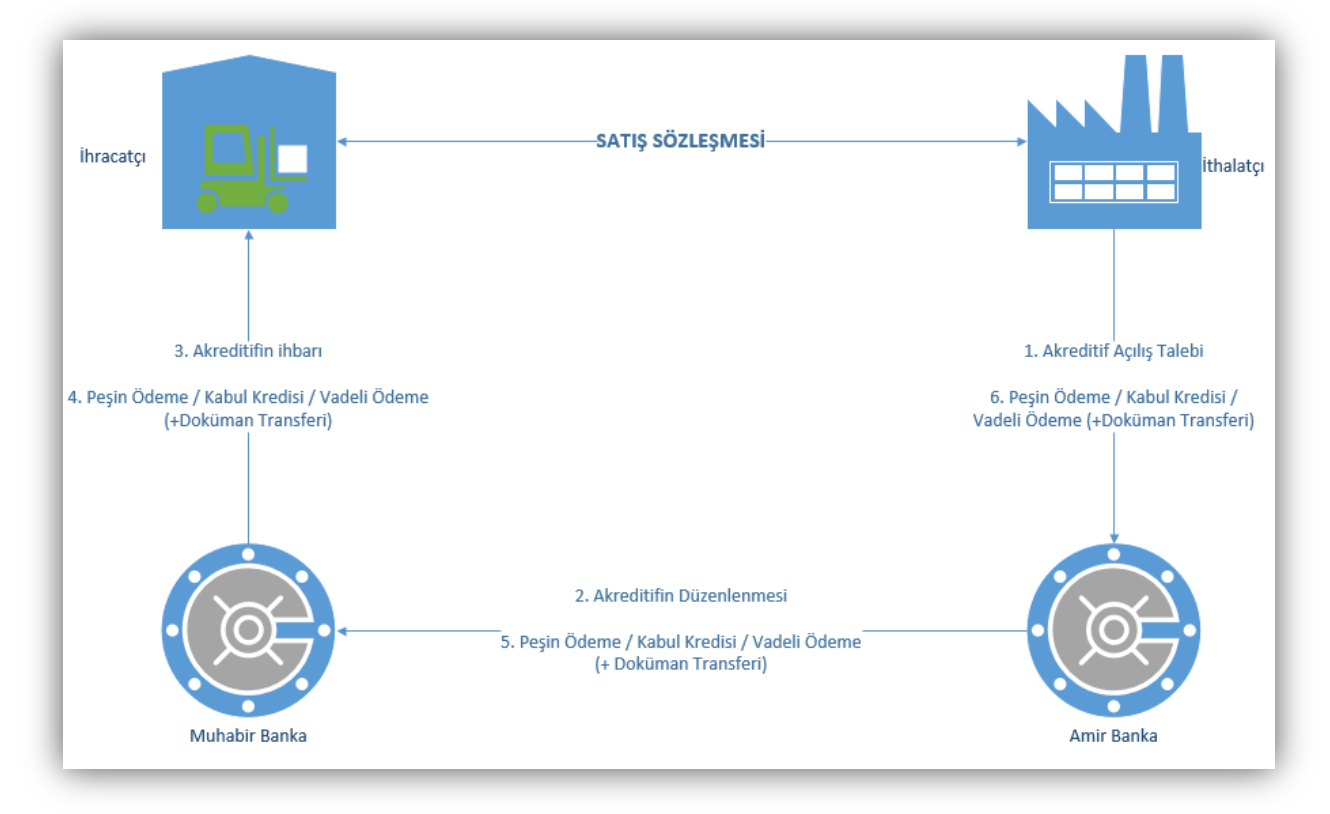

Şekil 1 - Akreditif Ödeme Şeklinin İşleyişi (Kaynak: Grath 2008, 54)

Yukarıda görüldüğü gibi akreditif süreci; satış sözleşmesinin ihracatçı ve ithalatçı arasında imzalanmasından sonra, ithalatçının kendi bankasına akreditif açtırma talebiyle başvurmasıyla başlamaktadır.

Akreditifi açan banka tüm prosedürlerin tamamlanmasını müteakiben, akreditifin ödeme şartlarında belirtildiği gibi ihbar bankasına (muhabir banka = ihracatçının bankası) ihbar edilmektedir.

Akreditifin SWIFT yoluyla ihbar bankasına ulaştırılmasının ardından ihbar bankası metni değerlendirecek ve ödemenin yapılacağı yeri belirleyecektir. Eğer ihbar bankası bu akreditife teyit verecekse, bu ayrı bir kredi limiti tesis etmek anlamına gelmektedir. $\mathrm{Bu}$ karardan da sonra ihbar bankası ihracatçıyı akreditif şartları ve özellikleri açısından bilgilendirmektedir. İhracatçı belirlenen akreditif şartlarını dikkatle incelemeli, satış sözleşmesi ile karşılaştırmalı, gerekirse akreditif metninde değişiklik talep etmelidir. 
Akreditif şartlarının kabul edilebilir olduğunun anlaşılmasından sonra sevkiyat gerçekleştirilir. Sevkiyatın ardından ihracatçı taşıma belgelerini alır ve diğer gerekli belgeleri hazırlar. $\mathrm{Bu}$ belgelerin ihbar bankasina sunulması ve banka tarafindan denetlenmesi sağlanır. Ancak bu aşamadaki ihtilaflar (rezervler) düzeltilebilir nitelikte değildir (örneğin; sevkiyat bilgilerinin hatalı olması veya belgelerin geç ibrazı v.b.). Bu aşamadaki ihtilaflar amirin (ithalatçının) onayına bağlı olacaktır. Rezervlerin mevcut olması ve alıcıdan onay beklenmesi aşamasında ihbar bankasının ihracatçıya yapacağı her ödeme, kabili rücu ödeme olacaktır. Yani ithalatçının akreditifteki rezervleri kabul etmemesi durumunda, ihbar bankası amir bankadan ödeme alamayacaktır. Bu nedenle ihracatçıya başvurarak kredi bedelinin kendisine ödenmesini talep edecektir. Bu aşama sonunda, evrak rezervsiz olarak veya alıcının onayına bağlı rezervli bir şekilde ithalatçının bankasına gönderilmektedir.

Akreditifi açan banka ve alıcı gelen belgeleri kontrol etmekte rezervler konusunda çalışma yapmak durumundadır. Eğer belgeler akreditif metni ile uyumluysa alıcı ödemekle mükelleftir. Belgelerin rezervli olması durumunda, belgeler ihbar bankasının emrine hazır bulundurulacaktır (ihracatçı ve ithalatçı arasındaki müzakerelerin sonuçlanmasına kadar askı halinde kalacaktır). Veya ihracatçıya ihbar bankası tarafından yapılan daha önceki ödemelere ilişkin olarak kredi bedelinin ihracatçıdan geri çağrılması amacıyla ihbar bankasına iade edilecektir.

Amir banka veya amir tarafindan belgelerde rezerv bulunamaması durumunda görüldügüünde ödemeli olarak veya vadeli ödeme yöntemiyle ödenmek üzere belgeler ithalatçıya verilmektedir.

\subsection{Fayda ve Avantajları}

Ödeme şekillerinin satıcı ve alıcı için farklı riskleri, farklı risk düzeyleri bulunmaktadır. Söz konusu riskler Tablo 1'de gösterilmektedir. Görüldüğü üzere, ihracatçı için en riskli ödeme şekli mal mukabili iken, ithalatçı için peşin ödemedir.

Tablo 1 - Ödeme Şekillerine Göre Risk Düzeyi

\begin{tabular}{|c|c|c|c|c|}
\hline \multicolumn{2}{|c|}{ Risk Düzeyi } & Ödeme Yöntemi & \multicolumn{2}{|c|}{ Risk Düzeyi } \\
\hline & $\mathbf{A z}$ & & Çok & \\
\hline \multirow{4}{*}{ 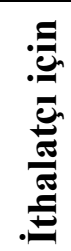 } & \multirow{4}{*}{5} & Mal Mukabili & & \multirow{4}{*}{ 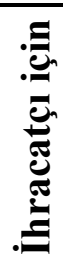 } \\
\hline & & Vesaik Mukabili & & \\
\hline & & Akreditif & & \\
\hline & & Peşin Ödeme & & \\
\hline \multicolumn{2}{|r|}{ Cok } & & $\mathbf{A z}$ & \\
\hline
\end{tabular}

Akreditifin ihracatçı açısından birçok faydası bulunmaktadır. Öncelikle ödeme konusunda bir banka garantisi mevcuttur. Akreditif metninde istenen belge ve şartlara uyulması durumunda satılan malın/hizmetin bedelinin ödenmemesi risk oldukça makul seviyelere inmektedir (Grath 2008, 49).

Alıcı açısından, pahalı bir yöntem olarak görülse de akreditifin bazı avantajları bulunmaktadır. Bazı durumlarda gerek söz konusu malların zamanında teslim edilmesi, gerek istenen mallara ilişkin belgelerin tam olarak düzenlenmesi alıcı açısından kritik önem taşıyabilir. Bu durumlarda akreditif alıcının amaçlarına hizmet etmektedir. 


\subsection{Dünyada ve Türkiye'de Akreditif Kullanımı}

Dünya ticaretindeki akreditifle gerçekleştirilen işlem hacmine baktığımızda 2011 y1lındaki dünya ticaret hacminin \%12,5'unun akreditif ödeme yöntemiyle gerçekleştirildiği ifade edilmektedir (Niepmann, Schmidt-Eisenlohr, 2016). Yine, Dünya Ticaret Örgütü tarafından yapılan bir çalışmada, dünya ticaretinin üçte birinin bankaların aracılık ettiği ticaret finansmanı ürünleriyle desteklendiği ve 2011 yılındaki dünya ticaret hacminin 2,8 trilyon ABD Doları tutarındaki kısmının akreditifle gerçekleştirildiği ifade edilmektedir (WTO, 2016, ss. 12 - 13). Öte yandan, aşağıda dünyanın en büyük on ithalatçısı ve ihracatçısının akreditif kullanım oranları yer almaktadır. Örneği; ihracatta olduğu kadar ithalatı da en yüksek ülkelerden biri olan Çin, ithalatının 3'te birinden fazlasını akreditif ödeme şekli ile gerçekleştirmektedir. Bu oran ABD için çok düşük seviyelerde kalmaktadır.

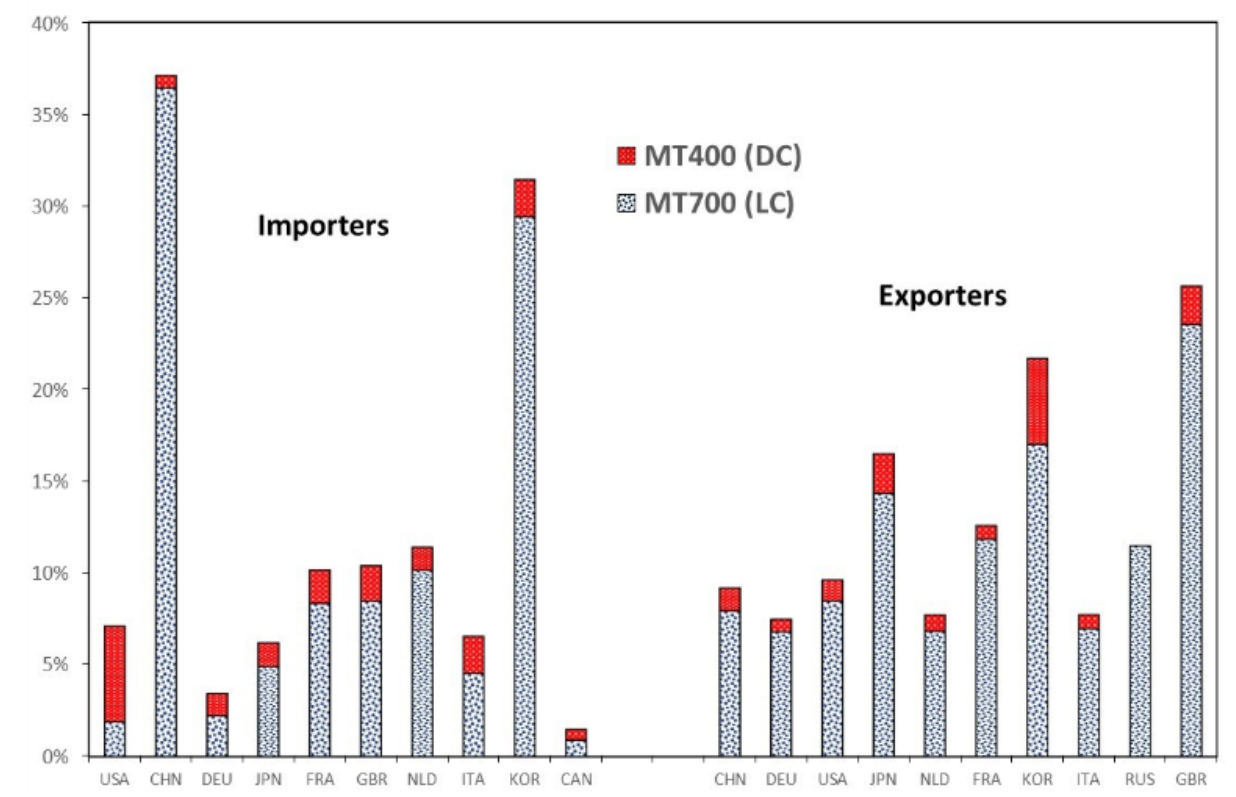

Şekil 2- İhracat ve İthalatta İlk 10 Sırada Yer Alan Ülkelerde Akreditif Kullanımı

(Kaynak: Swift Institute and IMF Directions of Trade Statistics, Niepmann, Schmidt-Eisenlohr, 2016)

Tablo 3'te yer aldığı gibi ülkemiz ihracatının büyük oranda mal mukabili ödeme şekli ile gerçekleştirildiği görülmektedir. Her ne kadar akreditifli ödemenin payı toplam ihracat içinde $\% 7$ civarında seyretse de akreditifli ödeme yönteminin her iki tarafa verdiği güven sebebiyle önemini koruyacağı düşünülmektedir.

Tablo 2 - Ödeme Şekilleri Bazında İhracat Tutarları (Türkiye İhracatı)

\begin{tabular}{|c|c|c|c|c|c|c|}
\hline Ödeme Şekilleri & 2017 & $\%$ & 2016 & $\%$ & 2015 & $\%$ \\
\hline $\begin{array}{l}\text { Toplam } \\
\text { (bin USD) }\end{array}$ & 157.055 .371 & 100 & 142.529 .584 & 100 & 143.838 .871 & 100 \\
\hline Mal Mukabili & 99.857 .810 & 64 & 94.964 .745 & 66 & 95.049 .619 & 66 \\
\hline Peşin & 23.534 .247 & 15 & 16.955 .195 & 12 & 15.361 .748 & 11 \\
\hline $\begin{array}{l}\text { Vesaik } \\
\text { Mukabili } \\
\end{array}$ & 21.656 .309 & 14 & 20.768 .116 & 15 & 21.555 .538 & 15 \\
\hline Akreditif & 11.417 .239 & 7 & 9.824 .336 & 7 & 11.835 .592 & 8 \\
\hline Diğer & 589.766 & 0 & 17.192 & 0 & 36.374 & 0 \\
\hline
\end{tabular}

(Kaynak: TÜİK, 2018) 


\section{Akreditifte Teyit Mekanizması ve Önemi}

İhracatından doğan alacağını güvence altına almak isteyen ihracatçının önünde bazı seçenekler bulunmaktadır. Bunlar; malını sattığı müşterisini tanımak, ihracat kredi sigortası yaptırmak, alacağını bir senede bağlamak, daha güvenilir bir ödeme şekli olan akreditifi tercih etmek gibi çeşitli yöntemler sayesinde gerçekleştirilebilir.

Her ne kadar amir banka akreditif şartlarına uyulması kaydıyla ihracatçının alacağını garanti etse de son dönemde de sıç̧a rastladığımız gibi bazı dönemlerde yaşanan politik ve ekonomik problemler ihracatçıları daha güvenli yöntemler bulmaya zorlamaktadır. Bahse konu riskler sebebiyle amir bankaların yükümlülüklerini yerine getiremeyebileceği veya ithalatçının ülkesindeki döviz sıkıntısı sebebiyle akreditif bedelini döviz cinsinden transfer etmekte zorlanabileceği durumlarla karşılaşılabilmektedir (Grath, 2008, 51).

Örneğin; Zimbabve'den herhangi bir bankadan Türkiye'de yerleşik bir ihracatçı lehine açılan akreditifte, ihracatçı firmanın Zimbabve'deki bankacılığı ve amir bankanın finansal durumunu bilmesi çok büyük ihtimalle mümkün olmayacaktır. Ancak bu akreditifin bir Türk bankası tarafından teyit edilmesi durumunda, ihracatçı için hem Zimbabve'nin ülke riski hem de Zimbabve bankasının ödememe riski ortadan kalkacaktır.

Teyitli akreditifler sayesinde genellikle uluslararası kurallarla daha bağlı bankalar ile çalışma firsatı da elde edilmekte, böylece akreditifte rezerv oluşması büyük ölçüde engellenmektedir.

Teyit masrafının \%2 ilâ \%8 arasında değiştiği ifade edilmektedir. (Yılmazcan, 2015, s. 49).

\section{Akreditif Teyit Sigortası}

Çalışmada akreditifin taraflara sağlayacağı avantajlardan bahsedilmişti. Bazı durumlarda ihracatçılar yurtdışında yerleşik amir bankaya da güvenememekte ve yurtiçindeki bir bankanın teyidini eklemesini talep etmektedir. Böylece, amir bankanın her ne kadar ödeme yükümlülüğü bulunsa da, finansal durumunun kötüleşmesi sonucu ödeme yapamaması durumunda borçtan teyit bankası sorumlu olacaktır.

Akreditif teyit sigortası; genellikle yurtiçinde yerleşik teyit bankasının alıcının bankası olan amir bankanın riskini üstlenmek istememesi veyahut mevcut limitinin hâlihazırda dolu olması gibi sebeplerle ön plana çıkmış bir alacak sigortası alt dalıdır.

Akreditif teyit sigortasında; normal koşullar altında, yurtdışındaki amir bankanın riskini üstlenemeyecek bir banka, genellikle ihracatı teşvik amacı güden bir sigorta kuruluşu tarafından sigorta teminatı alarak, ilgili amir bankanın açtığı akreditife teyit vermektedir. Özel sektörün ihracatı teşvik gibi bir amacı olmadığı, buna karşın resmi ihracat kredi sigortası kuruluşlarının amaçlarının bu olduğu düşünüldügünde bahsi geçen ürünün esas itibariyle resmi ihracat destek kuruluşlarının görev alanında olduğu açıktır.

Çalışma kapsamında, dünyada bu ürünü sunan resmi ihracat destek kuruluşları araştırılmış ve bu ürünü sunduğu belirlenen 15 kuruluşun uygulamaları mukayeseli olarak incelenmiştir. 
Tablo 3- Akreditif Teyit Sigortası Hizmeti Sunan Resmi İhracat Destek Kuruluşları

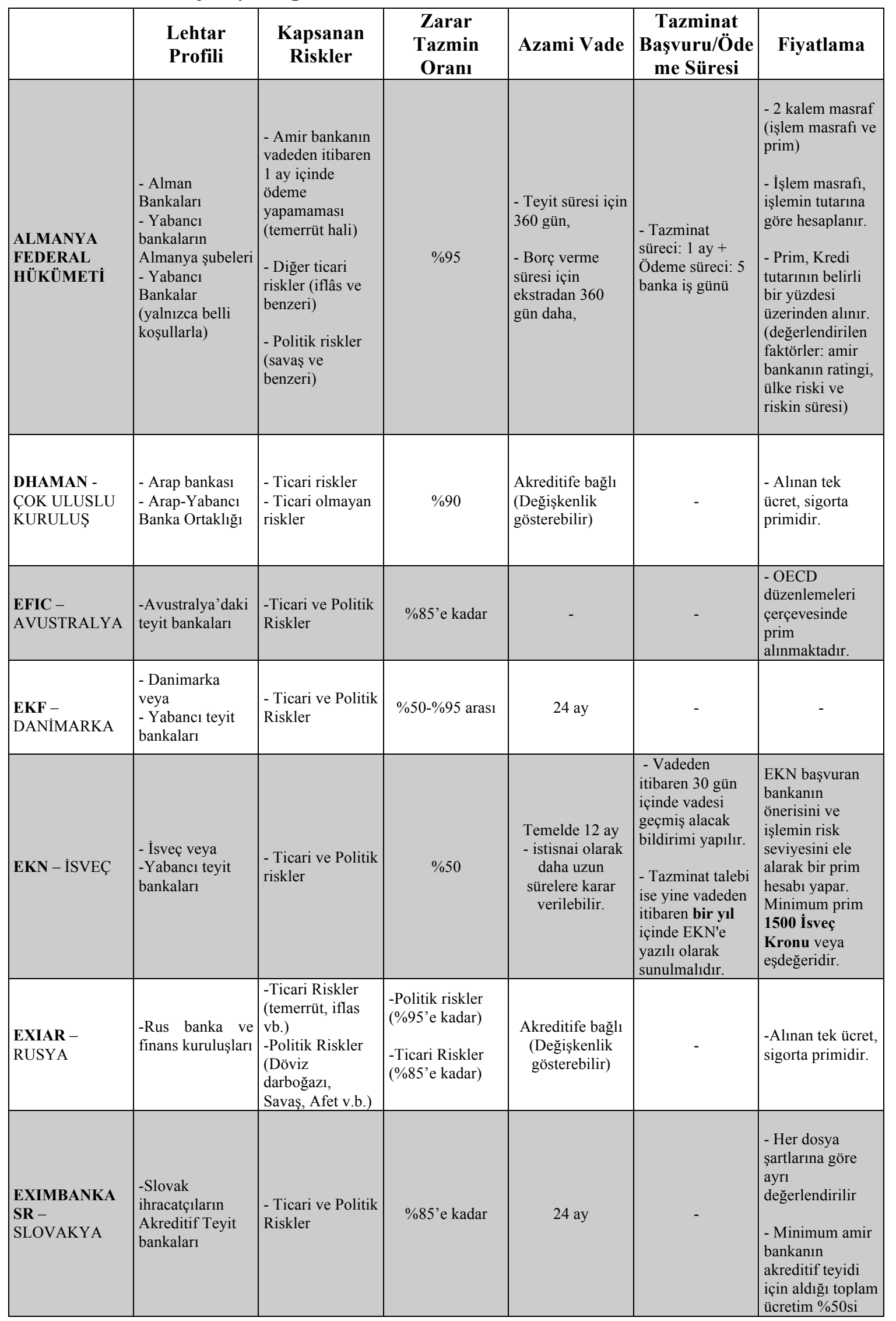




\begin{tabular}{|c|c|c|c|c|c|c|}
\hline & $\begin{array}{l}\text { Lehtar } \\
\text { Profili }\end{array}$ & $\begin{array}{c}\text { Kapsanan } \\
\text { Riskler }\end{array}$ & $\begin{array}{c}\text { Zarar } \\
\text { Tazmin } \\
\text { Oranı }\end{array}$ & Azami Vade & $\begin{array}{c}\text { Tazminat } \\
\text { Başvuru/Öde } \\
\text { me Süresi }\end{array}$ & Fiyatlama \\
\hline $\begin{array}{l}\text { FINNVERA - } \\
\text { FİNLANDIYA }\end{array}$ & $\begin{array}{l}\text { - Akreditifin Fin } \\
\text { ihracatçılara } \\
\text { yönelik olması } \\
\text { şartı ile } \\
\text { Finlandiya'daki } \\
\text { veya diğer } \\
\text { ülkelerdeki } \\
\text { bankalar }\end{array}$ & $\begin{array}{l}\text { - Ticari ve Politik } \\
\text { Riskler }\end{array}$ & $\begin{array}{l}\text { - Normal } \\
\text { kapsama halinde; } \\
\text { Ticari riskin } \\
\% 95 \mathrm{i}, \\
\text { Politik riskin } \\
\% 100 \text { ü } \\
\text { - Risk paylaşımı } \\
\text { halinde; } \% 50\end{array}$ & - & $\begin{array}{l}\text { Vade tarihinden } \\
\text { itibaren } 60 \text { gün } \\
\text { içinde tazminat } \\
\text { talebi } \\
\text { yapılmalıdır. } \\
\text { FINNVERA } 30 \\
\text { gün içinde } \\
\text { tazminat sürecini } \\
\text { sonuçlandırmakt } \\
\text { adır. }\end{array}$ & \begin{tabular}{|l} 
- Normal \\
kapsamada prim \\
amir bankanın ve \\
bankanın \\
ülkesinin kredi \\
değerliliğine, \\
akreditifin \\
geçerliliği ve \\
ödeme koşulları; \\
risk \\
paylaşımında ise \\
teyit bankasının, \\
akreditif için \\
aldığı ücret \\
üzerinden \\
hesaplanır. \\
- Her iki türde de \\
hizmet ücreti ek \\
olarak alınır.
\end{tabular} \\
\hline $\begin{array}{l}\text { GIEK - } \\
\text { NORVEÇ }\end{array}$ & $\begin{array}{|lr|}- & \text { Norveç'ten } \\
\text { ihraç } & \text { edilmiş } \\
\text { mallara } & \text { ilişsin } \\
\text { oluşturulan } & \\
\text { Akreditiflere } \\
\text { teyit } & \text { veren } \\
\text { bankalar } & \\
\end{array}$ & $\begin{array}{l}\text { - Ticari ve Politik } \\
\text { Riskler }\end{array}$ & $\% 50$ 'ye kadar & - & - & $\begin{array}{l}\text {-Akreditife bağlı } \\
\text { fiyatlama. (Alıcı } \\
\text { ülkesi, alıcının } \\
\text { finansal durumu } \\
\text { vb.) }\end{array}$ \\
\hline $\begin{array}{l}\text { ICIEC - } \\
\text { ÇOKULUSLU } \\
\text { KURULUŞ }\end{array}$ & \begin{tabular}{|l|}
-Üye ülkelerde \\
yerleşik bankalar \\
ve finansal \\
kuruluşlar \\
-\%50sinden \\
fazlasına İslami \\
Kalkınma \\
Bankası veya üye \\
ülkelerin sahip \\
olduğu, üye \\
olmayan \\
ülkelerde \\
yerleşik bankalar \\
ve finansal \\
kuruluşlar \\
- Şeriata uygun \\
ürünler sunan \\
bankalar ve \\
finansal \\
kuruluşlar \\
\end{tabular} & $\begin{array}{l}\text { - Ticari ve Politik } \\
\text { Riskler }\end{array}$ & $\% 90$ ' a kadar & 7 yıla kadar & - & - \\
\hline $\begin{array}{l}\text { OEKB - } \\
\text { AVUSTURYA }\end{array}$ & $\begin{array}{l}\text {-Avusturya'daki } \\
\text { bankalar }\end{array}$ & $\begin{array}{l}\text { - Ticari ve Politik } \\
\text { Riskler }\end{array}$ & $\% 100$ 'e kadar & 2 yıla kadar & - & $\begin{array}{l}\text {-İşlem ücreti } \\
(10 €-720 €) \\
\text {-Prim (Değişkenli } \\
\text { gösterir.) }\end{array}$ \\
\hline $\begin{array}{l}\text { SACE - } \\
\text { ITALYA }\end{array}$ & \begin{tabular}{|l|} 
İtalyan \\
ihracatçılar için \\
çıkarılan \\
akreditif \\
ödenmeme \\
riskine karşı teyit \\
veren bankalar \\
\end{tabular} & $\begin{array}{l}\text { - Ticari ve Politik } \\
\text { Riskler } \\
\text { (5m €'ya kadar) }\end{array}$ & - & 5 yıla kadar & - & Sowoun. \\
\hline $\begin{array}{l}\text { SERV - } \\
\text { İSVIÇRE }\end{array}$ & $\begin{array}{l}\text {-Akreditif teyidi } \\
\text { veren banka ve } \\
\text { finans kuruluşları }\end{array}$ & \begin{tabular}{|l|}
-Ticari Riskler \\
-Politik Riskler \\
-Kredi Riski \\
-Mücbir Sebep \\
\end{tabular} & $\% 95$ 'e kadar & & $\begin{array}{l}\text {-Tazminat } 30 \\
\text { gün içinde } \\
\text { ödenir. }\end{array}$ & $\begin{array}{l}\text { - Alınan tek } \\
\text { ücret, sigorta } \\
\text { primidir. }\end{array}$ \\
\hline $\begin{array}{l}\text { UKEF - } \\
\text { BİRLEŞIK } \\
\text { KRALLIK }\end{array}$ & $\begin{array}{l}\text {-UK'deki } \\
\text { bankalar }\end{array}$ & $\begin{array}{l}\text { - Ticari ve Politik } \\
\text { Riskler }\end{array}$ & $\% 90$ 'a kadar & 1 yıla kadar & - & \begin{tabular}{|l} 
- Teyit \\
masrafinın belirli \\
bir oranı olarak \\
teyit bankasından \\
tahsil edilir.
\end{tabular} \\
\hline
\end{tabular}




\begin{tabular}{|c|c|c|c|c|c|c|}
\hline & $\begin{array}{l}\text { Lehtar } \\
\text { Profili }\end{array}$ & $\begin{array}{c}\text { Kapsanan } \\
\text { Riskler }\end{array}$ & $\begin{array}{c}\text { Zarar } \\
\text { Tazmin } \\
\text { Oranı }\end{array}$ & Azami Vade & $\begin{array}{c}\text { Tazminat } \\
\text { Başvuru/Öde } \\
\text { me Süresi }\end{array}$ & Fiyatlama \\
\hline $\begin{array}{l}\text { US EXIM - } \\
\text { ABD }\end{array}$ & \begin{tabular}{|l|} 
- Amerikan \\
ürünleri \\
ihracatına veya \\
herhangi bir \\
yerde Amerikan \\
personel \\
tarafindan verilen \\
hizmetlere \\
yönelik \\
akreditiflere teyit \\
veren bankalar \\
(Amerikan \\
katkıs1 \%50'den \\
az ise kapsama \\
alınmaz - \\
savunma ürünleri \\
bu şarta bağlı \\
değildir).
\end{tabular} & $\begin{array}{l}\text { - Ticari ve Politik } \\
\text { Riskler }\end{array}$ & $\begin{array}{l}\text { - Kamu finans } \\
\text { kurumlarına } \\
\% 100 \text { 'e, } \\
\text { - Özel finans } \\
\text { kurumlarına } \\
\% 95 \text { 'e } \\
\text { - Belli tarım } \\
\text { ürünlerinde } \\
\% 98 \text { 'e kadar }\end{array}$ & 12 aya kadar & $\begin{array}{l}\text { - Vadeden } \\
\text { itibaren } 60-120 \\
\text { gün arasında } \\
\text { yapılmalıdır. } \\
\text { Vadeden itibaren } \\
30 \text { gün içinde, } \\
\text { ödeme ihtarı } \\
\text { amir bankaya } \\
\text { yapılmış } \\
\text { olmalıdır. } \\
\text { Tazminat, } \\
\text { evrakın tam } \\
\text { olarak } \\
\text { tesliminden } \\
\text { itibaren } 60 \text { gün } \\
\text { içinde ödenir. }\end{array}$ & $\begin{array}{l}\text { - Primler her } \\
\text { başvurunun } \\
\text { riskine göre } \\
\text { hesaplanır. } \\
\text { - Poliçenin } \\
\text { oluşturulmas1 } \\
\text { için } 2.000 \text { USD } \\
\text { depozito ödenir. }\end{array}$ \\
\hline
\end{tabular}

(Kaynak: Söz konusu tablo, ilgili ihracat kredi kuruluşlarının web sitelerinden elde edilen bilgiler, ilgili kuruluşların yetkilileriyle gerçekleştirilen görüşmeler sonucunda yazar tarafından oluşturulmuştur.)

\subsection{Akreditif Teyit Sigortası İş Akış Süreci}

Akreditif teyit sigortasında iş akış süreci aşağıdaki şekildedir:

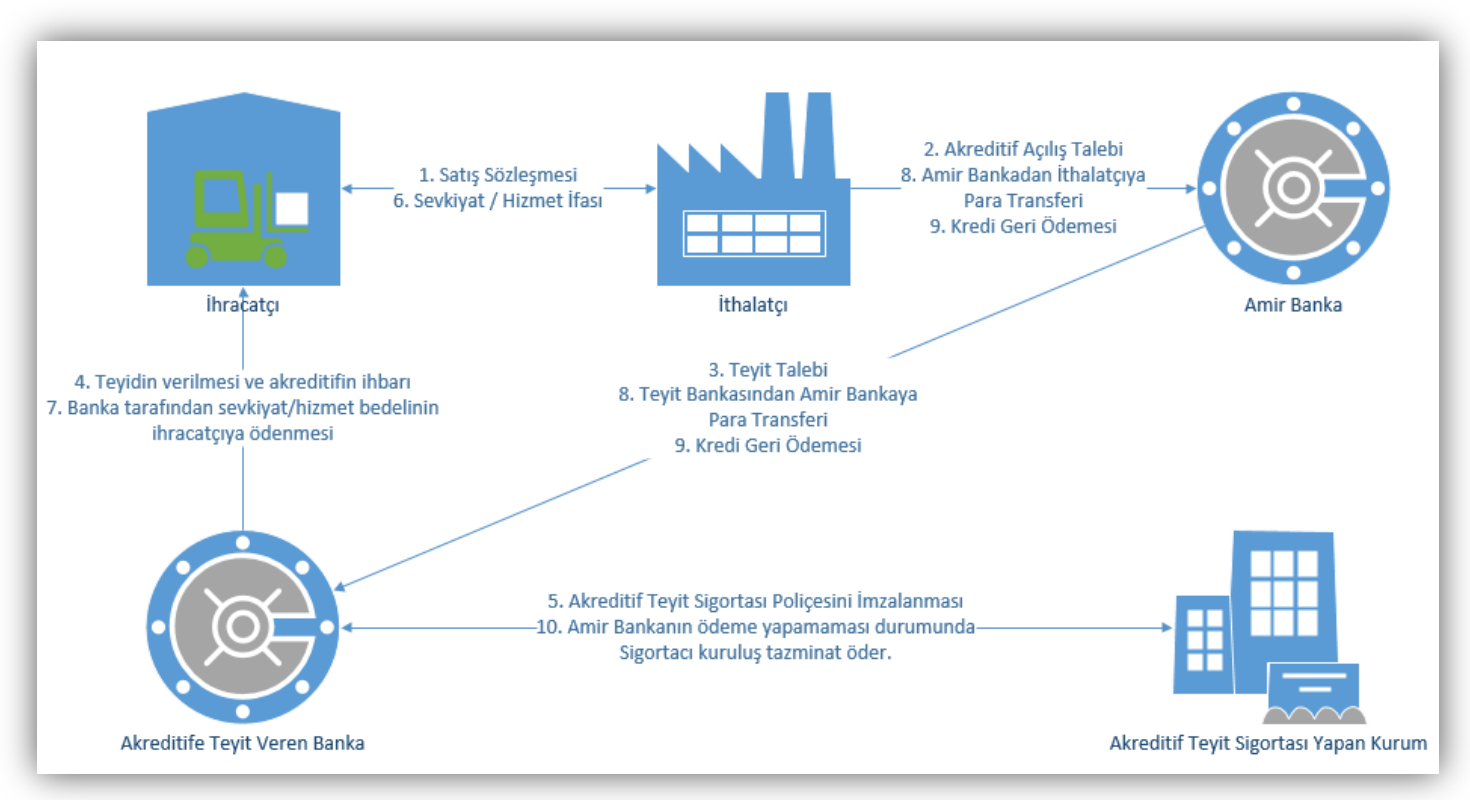

Şekil 3- Akreditif Teyit Sigortası İş Akış Şeması (Kaynak: EXIAR, 2018)

Birinci Aşama: İthalatçı ve ihracatçı akreditifli ödeme şekli şartı içeren bir satış sözleşmesi imzalamaktadır.

İkinci aşama: İthalatçı, ihracatçı lehine akreditif açtırmak üzere kendi bankasına başvurmakta ve bankası akreditif tesis etmektedir.

Üçüncü aşama: Kendini amir bankanın taşıdığı risklere karşı da güvende hissetmek isteyen ihracatçının yurtiçinden bir bankanın söz konusu akreditife teyit vermesini talep etmesi neticesinde, amir banka tarafindan, "teyit verilmesi talebiyle" ihracatçının bankasına başvurulmaktadır. 
Dördüncü ve beşinci aşama: Sürecin en önemli kısmı burada başlamaktadır. Gerek amir bankaya gerekse amir bankanın bulunduğu ülkeye tanımlanan banka içi limitlerin yetersiz kalması durumunda ihracatçının bankası akreditif teyit sigortası yaptırmak istemektedir. Dördüncü ve beşinci aşamanın yer değiştirmesi, ihracatçının bankasının sigortalanma talebinin zamanlamasına bağlı olarak değişebilmektedir.

İhracatçının bankası, gerekli bilgi ve belgelerle Akreditif Teyit Sigortası Yapan Kurum'a başvurmakta, talebi olumlu olarak değerlendirilirse, söz konusu akreditife teyit verilmesi akabinde ihracatçının bankasının lehine sigorta poliçesi düzenlenmektedir. Böylece teyit verilen akreditif, ihracatçıya ihbar edilmekte, akreditifte istenen belgelerin eksiksiz bir şekilde kendisine gönderilmesi talep edilmektedir.

Altıncı aşama: Yurtiçi bankanın teyidini alan ihracatçı sözleşme konusu $\mathrm{mal} /$ hizmeti sevk etmekte/ifa etmektedir.

Yedinci aşama: UCP 600'e (md. 15) göre görüldüğünde ödemeli bir akreditif söz konusu olduğunda teyit veren banka uygun belge ibrazı karşılığında akreditif bedelini ihracatçıya ödemektedir.

Vadeli akreditif söz konusu ise (available by deferred payment) teyit veren banka vadeli ödeme yükümlülüğüne girmekte ve ödeme vadesinde ödeme yapmaktadır.

Kabul kredili bir akreditif söz konusu ise (available by acceptance) lehtar tarafından çekilen poliçeyi kabul etmek ve poliçenin ödeme vadesinde ödeme yapmakla mükelleftir.

Sekizinci aşama (post finansman ${ }^{1}$ varsa): İşlemde bir post finansman söz konusu ise, yani akreditife teyit veren banka aynı zamanda alıcıya finansman sağlıyorsa bu aşamada gündeme gelmektedir.

Post finansman durumunda teyit veren banka tarafindan sağlanan finansman amir banka aracılığıyla ithalatçıya aktarılmaktadır. Daha sonra söz konusu kredinin vadesi geldiğinde, gerek akreditif bedeli gerekse post finansman bedeli amir banka aracılığıyla teyit veren bankaya aktarılmaktadır.

Dokuzuncu aşama: İthalatçı ilgili akreditife dair vadesinde ödeme yapsın veya yapmasın, amir banka ilgili akreditif bedelini teyit bankasına ödemekle mükelleftir.

Post finansman olduğu durumda aynı zamanda teyit bankası tarafından ithalatçıya verilen kredi bedeli de borç veren kuruluş olan teyit bankasına ödenir.

Onuncu aşama: Akreditifte yer alan ödeme vadesinde ilgili bedelin kendisine ödenmemesi üzerine, teyit bankası Akreditif Teyit Sigortası yapan kuruluşa giderek tazminat talep eder. Gerekli değerlendirme sonucu, tazminatı uygun bulunan dosyalara ilişkin olarak Akreditif Teyit Sigortası sağlayan kurum tarafindan tazminat ödemesi yapilir.

\footnotetext{
1 Post finansman: İthalatın finansmanında kullanılmak üzere, firmalarca yurtdışındaki satıcıdan veya uluslararası piyasalardan sağlanıp kullandırılan kredilerdir.
} 


\section{Akreditif Teyit Sigortası ve Benzer Enstrümanlar Arasındaki Farklar}

\subsection{Akreditif Teyit Sigortası ve İhracat Kredi Sigortası Arasındaki Farklar}

Temelde bir alacak sigortası dalı olan akreditif teyit sigortası ihracat kredi sigortasından belirli farklılıklar göstermektedir. Temel farklılıklar Tablo 5'te yer almaktadir.

\section{Tablo 4 - Akreditif Teyit Sigortası ve İhracat Kredi Sigortası Arasındaki Farklar}

\begin{tabular}{|l|l|}
\hline \multicolumn{1}{|c|}{ İhracat Kredi Sigortası } & \multicolumn{1}{c|}{ Akreditif Teyit Sigortası } \\
\hline Lehtar ihracatçıdır. & Lehtar akreditife teyit veren bankadır. \\
\hline $\begin{array}{l}\text { Üstlenilen riskin firma riski olması sebebiyle } \\
\text { göreli olarak pahalıdır. }\end{array}$ & $\begin{array}{l}\text { Üstlenilen riskin banka riski olması sebebiyle } \\
\text { göreli olarak ucuzdur. }\end{array}$ \\
\hline Satıcı/Tedarikçiyi korur. & $\begin{array}{l}\text { Amir bankanın ödeme yapmama/yapamama } \\
\text { riskine karşı teyit bankasını korur. }\end{array}$ \\
\hline $\begin{array}{l}\text { Ticari risk değerlendirmesinde, alıcı firmanın } \\
\text { analizi yapılır. }\end{array}$ & $\begin{array}{l}\text { Ticari risk değerlendirmesinde, amir bankanın } \\
\text { analizi yapılır. }\end{array}$ \\
\hline $\begin{array}{l}\text { Mali oran analizinde standart yöntemler } \\
\text { uygulanır. }\end{array}$ & $\begin{array}{l}\text { Mali oran analizinde CAMELS }{ }^{2} \text { metodu } \\
\text { uygulanır. }\end{array}$ \\
\hline $\begin{array}{l}\text { İhracatçının zararı, genelde \%90 - \%95 oranında } \\
\text { tazmin edilir. }\end{array}$ & Zarar tazmin oranı \%50 - \%100 bandındadır. \\
\hline $\begin{array}{l}\text { Sigortalama ihtiyacının temelinde ticari riskler } \\
\text { yatmaktadır. }\end{array}$ & $\begin{array}{l}\text { Sigortalama ihtiyacının temelinde politik riskler } \\
\text { yatmaktadır. }\end{array}$ \\
\hline $\begin{array}{l}\text { Genellikle ihracatçının tüm portföyü } \\
\text { sigortalanmaktadır. }\end{array}$ & $\begin{array}{l}\text { Terzi işi bir yöntemle, her bir akreditif için ayrı } \\
\text { bir poliçe düzenlenebileceği gibi farklı modellerle } \\
\text { de poliçe düzenlenebilir. Örneğin; tek bir amir } \\
\text { bankanın birden çok akreditifini kapsayan } \\
\text { işlemlerin ya da tek bir ülkeye yönelik olarak } \\
\text { teyit bankasının sigortalanması v.b. }\end{array}$ \\
\hline
\end{tabular}

Kaynak: (Atradius, 2017) (Grath, 2008, 53)

$\mathrm{Bu}$ iki ürün arasında, özellikle analizi gerçekleştirilen taraf farklılaşmaktadır. Alıcının analizi değil, akreditif amiri bankanın analizi önem taşımaktadır. Bu analiz aşağıdaki tablo temelinde gerçekleştirilmektedir:

2 CAMELS; Capital, Asset Quality, Management, Earnings, Liquidity ve Sensitivity to Market Risk kavramlarının baş harflerinden oluşan bir banka analiz yöntemidir (Atradius, 2017, s. 14). 


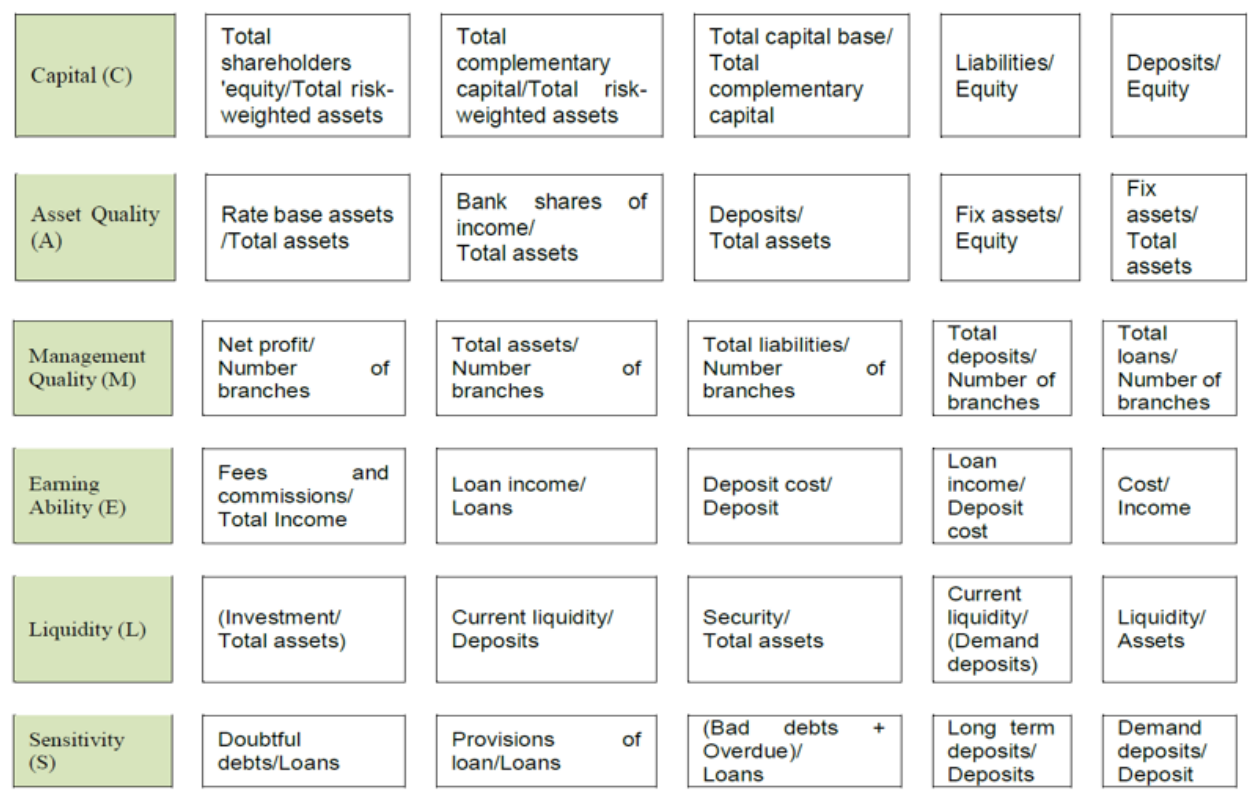

Şekil 4- CAMELS Analizinde Kullanılan Temel Oranlar (Kaynak: Atradius, 2017, s. 15)

\subsection{Akreditif Teyidi ve Akreditif Teyit Sigortası Arasındaki Farklar}

Tablo 5 - Akreditif Teyidi ve Akreditif Teyit Sigortası Arasındaki Farklar

\begin{tabular}{|l|l|}
\hline \multicolumn{1}{|c|}{ Akreditif Teyidi } & \multicolumn{1}{c|}{ Akreditif Teyit Sigortası } \\
\hline Lehtar ihracatçıdır. & Lehtar akreditife teyit veren bankadır. \\
\hline $\begin{array}{l}\text { Teyit bankası zarar bedelini ihracatçıya ödedikten } \\
\text { sonra tekrar ihracatçıya bu zararla ilgili rücu } \\
\text { edemez. }\end{array}$ & $\begin{array}{l}\text { Sigorta veren makam, yaptığı tazminat ödemesi } \\
\text { sonrasında haksız yere ödeme yaptığını anlarsa, } \\
\text { ilgili meblağ1 lehtardan talep edebilir. }\end{array}$ \\
\hline $\begin{array}{l}\text { İhracatçı ve ithalatçı arasındaki sözleşmeden } \\
\text { bağımsız bir iliş̧idir. Teyit veren bankaya, } \\
\text { inceleyebileceği geniş bir alan tanımaz. }\end{array}$ & $\begin{array}{l}\text { İhracatçı ve ithalatçı arasındaki sözleşme de dâhil } \\
\text { olmak üzere sigorta veren kuruma } \\
\text { inceleyebileceği geniş bir alan verir. }\end{array}$ \\
\hline $\begin{array}{l}\text { Akreditifte yazan tutarın tamamı ödenir. İhracatçı } \\
\text { üzerinde risk bırakılmaz. }\end{array}$ & $\begin{array}{l}\text { Zararın belirli bir kısmı ödenir (uygulamada \%50 } \\
-\% 100 \text { arasında). Kalan kısım lehtar üzerinde } \\
\text { bırakılır. }\end{array}$ \\
\hline
\end{tabular}

(Kaynak: Durukanoğlu, 2008, s. 221)

\section{Akreditif Teyit Sigortası'nın Fayda ve Avantajları}

Akreditif teyit bankalarının lehtarı olduğu akreditif teyit sigortasının temel amacı teyit bankalarının akreditif teyit kapasitesini artırmaktır (ICIEC, 2018, s.1). Bu vesileyle ülke ihracatının artması ve ihracat alacaklarının teminat altına alınması sağlanmakta; böylece yeni ihracat olanakları açısından finansman sağlanmaktadır. Öte yandan, teyit bankasının, ihracatçının performansından emin olduğu durumlarda ilgili akreditifi iskonto ederek ek bir işletme sermayesi oluşturması da ürünün, sayılabilecek bir diğer faydasidır (EFIC, 2018).

Teyit bankasının bilançosu amir bankanın ödeme yükümlülüğünü yerine getirememe riskine karşı tehdit altındadır. Akreditif teyit sigortası vasıtasıyla teyit bankası, bilançosunu bu tür risklere karşı korumuş, riski makul seviyelere indirmiş olacaktır (ICIEC, 2018, s.1).

Akreditif teyit sigortası, bir yandan akreditiflere teyit verilmesini kolaylaştırırken bir taraftan da ihracatın coğrafi çeşitliliğinin artmasına imkân tanımaktadır. 
Vadeli akreditiflerin de akreditif teyit sigortası kapsamında olması, ihracatçıların daha uzun vadeli akreditiflerine dahi teyit bulabilmelerine imkân tanımakta, böylece ihracatçıların rekabetçi üstünlük elde etmesine zemin hazırlanmaktadır.

Birinci sınıf bir teminat olarak kabul edilen akreditif teyit sigorta poliçesi sayesinde tutulması gereken zorunlu karşılıklar minimuma indirilmektedir.

Rusya ihracat destek kurumu EXIAR, akreditif teyit sigorta poliçesi sayesinde; anaparaya ek olarak, sigorta priminin de finanse edilmesi için verilen banka kredisinin de sigortalanabildiğini ifade etmektedir.

Akreditif teyit sigortası satın alan bankaların sermaye yükleri hafiflemektedir (EXIAR, 2018). EXIAR'dan bu tür bir sigortayı temin eden bankaların borç verme şartları ve ilgili faize ilişkin şartlar 3. derecedeki varlık grubuna göre belirlenmektedir.

Akreditifte yer alan ihbar bankasından teyit talebinde bulunulduğunda ihbar bankası bazı zorluklarla karşılaşabilmektedir. Bu zorluklardan en önemlileri; amir bankaya veya amir bankanın yerleşik bulunduğu ülkeye olan limitin yetersizliğidir. Alman Federal Hükümeti teşvik mekanizmaları arasında yer alan Akreditif Teyit Sigortası sayesinde bu limitler yükseltilerek Almanya ihracatının artırılması mümkün olmaktadır (Alman Federal Hükümeti, 2017, s. 2).

\section{Uygulama Örneği}

Akreditif teyit sigortasını aktif olarak kullanan ICIEC (The Islamic Corporation for the Insurance of Investment and Export Credit) tarafindan hâlihazırda sigorta kapsamına alınmış, gerçek bir işleme ait şema aşağıda sunulmaktadır.

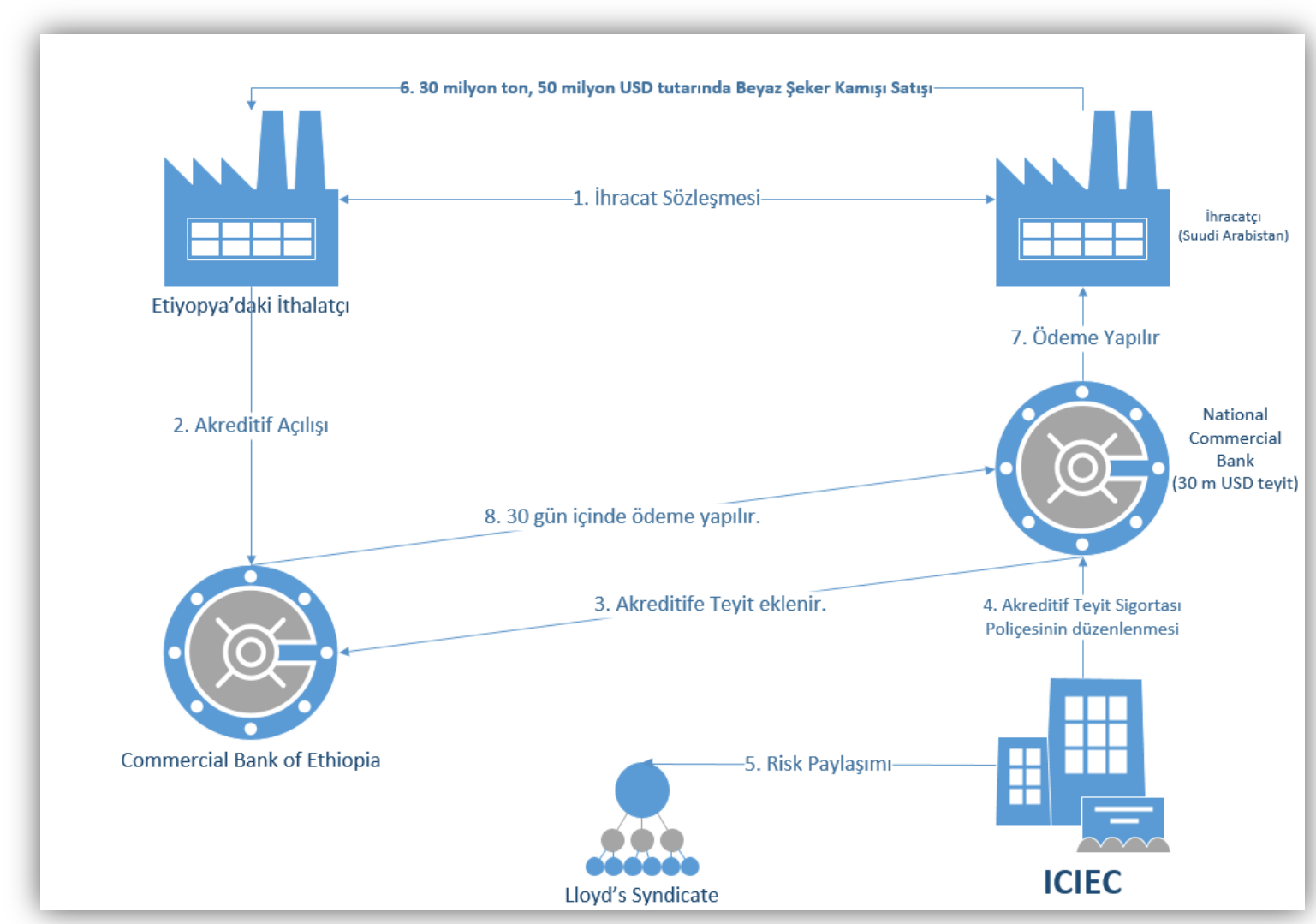

Şekil 5- Uygulama Örneği (ICIEC) (Kaynak: ICIEC Tanıtım Sunumu, Haziran 2014, s.32) 
Birinci Aşama: Yukarıda ifade edilen örnek işlemde, Suudi Arabistan'dan Etiyopya'ya 30 milyon ton şeker kamışı ihracatı hususunda ihracatçı ve ithalatçı anlaşmaya varmıştır.

İkinci Aşama: Söz konusu ihracat işlemiyle ilgili olarak Etiyopya'daki ithalatçının bankası (amir banka) Commercial Bank of Ethiopia tarafından Suudi Arabistan'daki ihracatçı lehine akreditif açılmıştır.

Üçüncü Aşama: Söz konusu akreditifin 30 milyon ABD Doları tutarındaki kısmına ilişkin olarak Suudi Arabistan'daki National Commercial Bank (NCB) tarafından teyit verilmiştir.

Dördüncü Aşama: Teyit Bankası olan NCB, ICIEC'e başvurarak akreditif teyit sigortası poliçesi yaptırmıştır. ICIEC, 30 milyon ABD Doları'nın 20 milyon ABD Dolarlık kısmını sigortalamıştır.

Beşinci Aşama: ICIEC, üstlendiği riski reasüre ettirmek amacıyla Londra merkezli Lloyd's piyasasına başvurmuştur.

Altıncı Aşama: Suudi Arabistan'daki ihracatçı tarafından Etiyopya'daki ithalatçıya 30 milyon ton şeker kamışı ihraç edilmiştir.

Yedinci Aşama: Gerekli evrakın sunulması ile birlikte teyit bankası NCB, ihracatçıya mal bedelini ödemiştir.

Sekizinci Aşama: 30 günlük vade sonunda amir banka (Commercial Bank of Ethiopia) tüm akreditif bedelini ihracatçının bankası olan NCB’ye ödemiştir.

\section{Sonuç ve Tartışma}

Her ne kadar dünya ticaretinde artan rekabet, satıcıları mal mukabili satış yapmaya zorlasa da akreditifin uluslararast ticaretin can damarl olduğu ifade edilmektedir. Nitekim Dünya Ticaret Örgütü, IMF ve BAFT (Bankers' Association for Finance and Trade) yayınlarında, dünya ticaret hacminin üçte birinin bankalar aracılığ 1 ile gerçekleştirildiği belirtilmektedir. Akreditifli işlemlerin bu hacmin \%12 - \%15'i arasında olduğu tahmin edilmektedir.

İthalatçı firmalardan olan alacaklarının ödenmeme risklerine karşı kendilerini güvence altına almak isteyen ihracatçılar ödeme şekli olarak akreditifi tercih etmektedirler. Ancak, çalışmamızda bahsettiğimiz gibi akreditif ödeme şekli dahi ihracatçıya tam bir güvence sağlayamamaktadır. Nitekim, amir bankanın finansal durumunun negatif hale gelmesi ya da amir bankanın ülkesinde yaşanan politik olaylar neticesinde ihracatçının alacağını alamama riski doğabilmektedir. Bu tür durumlarda talep edilen sigorta ürünü Akreditif Teyit Sigortası olmaktadır.

Ülkemizde akreditif kullanımı 2017 yılı itibariyle 11 milyar ABD Doları (toplam ihracatın \%7'si) seviyesindedir. Ancak, akreditif teyit sigortası sunulamadığı için gerçekleştirilememiş ihracat hacminin ne olduğu bilinememektedir. Akreditif teyit sigortası, teyit bankasına ve ihracatçıya sağlayacağı güvence ile ihracatçıların daha fazla ihracat yapmalarını sağlayacak bir ürün olarak ön plana çıkacağı düşünülmektedir. Nitekim reel sektörle yapılan görüşmeler de bu tür bir ürüne talep olacağını göstermiştir.

Bahse konu ürünün yaratacağı etkiler düşünüldüğünde, Türkiye'deki akreditif hacmini olumlu yönde etkileyeceği görülmektedir. Bankaların akreditif 
komisyonlarında oluşturacağı etki ise bankaların ürüne bakış açısına göre değişebilir. Bankalar Akreditif Teyit Sigortası olmadığı durumda kaybedecekleri teyit gelirlerini düşünerek ihracatçı için ek bir maliyet oluşturmayabilirler. Ancak bunu teyit masrafını yükselterek ihracatçıya yansıtmaları da mümkündür. $\mathrm{Bu}$ müzakerenin nasıl sonuçlanacağı hususunda, müşteri ve bankanın rekabet gücü belirleyici olacaktır.

Özellikle riski yüksek coğrafyalar için talep göreceği aşikâr olan ürünün, bölge özelinde Afrika, Orta Doğu ve Orta Asya Türki Cumhuriyetlerinde yerleşik amir bankaların risklerine yönelik olarak işlem görmesi beklenmektedir. Bu bölgelerle aramızda bulunan tarihi ve kültürel bağlar yanında ekonomik bağın güçlenmesine de katkıda bulunacak, Türkiye Cumhuriyeti Devleti'ne ait Türk Eximbank tarafindan sunulması vesilesiyle bu ülkelerdeki finansal kuruluşlar ile ülkemiz finansal kesimi arasında bir köprü vazifesi görebilecektir.

Türkiye'de henüz uygulanmaya başlanmayan; ancak dünya çapında birçok İhracat Destek Kuruluşu'nun ürün yelpazesinde yer alan Akreditif Teyit Sigortası'nın Türkiye'nin resmi ihracat destek kuruluşu Türk Eximbank tarafindan hizmete sunulması ihracat hacmini artıracak bir unsur olacaktır. 


\section{Kaynakça}

Atradius, Presentation to Türk Eximbank, Eugene O'Keane, (Senior Manager, Commercial), 20.09.2017, İstanbul.

DHAMAN, http://dhaman.net/en/our-products/bank-insurance/confirmed-documentarycredit-insurance-policy/ (Erişim Tarihi: 21.02.2018)

Durukanoğlu, N. (2008). Dış Ticaret Dünyası: Örnek Olay ve Tablolar, Beta Yayınları, 128-129.

EFIC - Export Finance and Insurance Corporation (Australia), https://www.efic.gov.au/ business-solutions/individual-solution-pages/documentary-credit-guarantee (Erişim Tarihi: 21.02.2018)

EKF (Denmark's official export credit agency), http://www.ekf.dk/en/WhatWeDo /EKFs_guarantees/Pages/l-c-guarantee.aspx (Erişim Tarihi: 20.02.2018)

EKN (Exportkreditnämnden) - Sweden, The Swedish Export Credit Agency, https://www.ekn.se/globalassets/dokument/faktablad/banker/en/letter-of-creditguarantee.pdf (Erişim Tarihi: 20.02.2018)

Euler Hermes Aktiengesellschaft, (2017). Export Credit Guarantees of The Federal Republic of Germany, Product Information - Credit Confirmation Risk Cover.

Export-Import Bank of The Slovak Republic, https://www.eximbanka.sk/en/english/ our-products/insurance-products/l-insurance-of-a-confirmed-export-irrevocabledocumentary-letter-of-credit.html?page_id=473 (Erişim Tarihi: 18.02.2018)

Federal Republic of Germany, https://www.agaportal.de/_Resources/Persistent/ d72b6bfa35b1175159284981cd6692f3baabf5f4/e_pi_akkreditivrisikodeckung.pdf (Erişim Tarihi: 19.02.2018)

Ferguson, N., (1983). "Innovations In The Approach of Merchant and Trading Banks to Financing Overseas Sales" in CM Chinkin, PJ. Davidson and WJM Ricquier (eds), Current Problems of International Trade Financing, Butterworths, Singapore.

FINNVERA, The Official Export Credit Agency (ECA) of Finland, https://www.finnvera.fi/eng/products/export-credit-guarantees/letter-of-creditguarantee (Erişim Tarihi: 19.02.2018)

GIEK - (Norwegian Export Credit Guarantee Agency), https://www.giek.no/letter-ofcredit-guarantee/ (Erişim Tarihi: 21.02.2018)

Grath, A. (2008). The Handbook of International Trade and Finance, Kogan Page Limited, Great Britain and USA.

ICIEC - The Islamic Corporation for The Insurance of Investment and Export Credit, www.iciec.com/solutions.php (Erişim Tarihi: 20.02.2018)

ICIEC, (2018), DCIP Introduction.

ICIEC, (2014). Tanitım Sunumu.

International Monetary Fund - Bankers' Association for Finance and Trade (IMFBAFT), (2009). "IMF-BAFT Trade Finance Survey: A Survey Among Banks Assessing The Current Trade Finance Environment", Washington DC: FImetrix For The IMF and BAFT.

Mcluhan, M., Powers, B., (1988), The Global Village: Transformations in World Life and Media in The 21 st Century, Oxford University Press. 
Mugasha, A., (2003). The Law of Letters of Credit and Bank Guarantees, The Federation Press.

Niepmann, F., Schmidt-Eisenlohr, T., (2016). "Trade Finance Around The World" https://voxeu.org/article/trade-finance-around-world (Erişim Tarihi: 14.02.2018)

OECD, (2008). Export Credit Financing Systems in OECD Member Countries and Non- Member Economies, OECD Library, ISSN: 2074-322X.

OEKB - Austria, Oesterreichische Kontrollbank AG https://www.oekb.at/en/exportservices/protecting-and-financing-exports/protection-of-letter-of-creditconfirmations.html (Erişim Tarihi: 20.02.2018)

Özelge, E.G., (2015). “Akreditif Teyit Sigortası ve Türk Eximbank'a Uygulanabilirliği”, Türk Eximbank Uzmanlık Tezi, İstanbul.

Polat, A. (2008). "Uluslararas1 Ticarette Akreditifli Ödemeler ve UCP 600", İstanbul Ticaret Ünv. Sos. Bilimler Dergisi, Yıl: 7 sayı: 13 Bahar 2008, 209-222.

Russian Agency for Export Credit and Investment Insurance (EXIAR), https://www.exiar.ru/en/products/2199/ (Erişim Tarihi: 20.02.2018)

SACE - Italy, https:/www.sace.it/en/products-and-services/products/confirmation-ofletters-of-credit-policy (Erişim Tarihi: 20.02.2018)

SERV - Switzerland, https:/www.serv-ch.com/en/products/productfinancing/letter-ofcredit-confirmation-insurance/ (Erişim Tarihi: 20.02.2018)

TÜİK, Kaynak: http://www.tuik.gov.tr/PreIstatistikTablo.do?istab_id=640 (Erişim Tarihi: 14.02.2018)

UKEF - United Kingdom, https://www.gov.uk/guidance/letter-of-credit-guaranteescheme-overview-and-how-to-apply (Erişim Tarihi: 19.02.2018)

U.S. EXIM - https://www.exim.gov/what-we-do/export-credit-insurance/letter-credit (Erişim Tarihi: 13.02.2018)

Yılmazcan, A., (2015). "UCP 600 Kuralları Çerçevesinde Akreditifin İşleyişi, Yüksek Lisans Tezi”, Ankara, T.C. Ankara Üniversitesi Sosyal Bilimler Enstitüsü Özel Hukuk (Deniz Hukuku) Anabilim Dal1, Ankara.

World Trade Organization, (2016). "Trade Finance and SMEs - Bridging The Gaps in Provision". 


\title{
Letter of Credit Confirmation Insurance, The Implementation in Turkey and Possible Effects
}

\author{
Mehmet YEŞILILAPRAK \\ Turk Eximbank \\ Head of Department / Insurance and Treasury Operations \\ Istanbul, Turkey \\ orcid.org / 0000-0001-8334-5191 \\ myesilyaprak@eximbank.gov.tr
}

\section{Extensive Summary}

Last figures show that international trade is improving constantly even though some fluctuations happen sometimes and the acceleration of export and import volumes show that new economic operators/actors join to the sector. The countries claiming themselves as the most closed economies start to realize that they should enter the globalization circle in order to move in their development way, and they give importance to the exportation.

There are four payments methods (payment terms) in international trade: cash, cash against documents, cash against goods and letter of credit (L/C). Banks have important duties in $\mathrm{L} / \mathrm{C}$ transaction which can be defined as a contract which has a definite payment commitment between exporter and importer if both parties comply with the conditions of $\mathrm{L} / \mathrm{C}$. In practice, it seems that almost each $\mathrm{L} / \mathrm{C}$ conform to the UCP 600 rules published by ICC. L/Cs are the combinations of "bank guarantees" and "payments" which provide sight or deferred payment options by presenting related documents to the advising bank.

In this study; definition of L/C Confirmation Insurance, parties, work flow, the differences with alternative products, usage in Turkey / world and sample practices are examined. Also, it is assessed how this product would work in Turkish economical system and which risks/ which advantages will occur after using this product in the system.

Within this study, we examined Export Credit Agencies who provide this product and 15 institutions who are using this product are analyzed with a comparative method.

It is not a new practice to insure the shipments made through $\mathrm{L} / \mathrm{Cs}$, on the contrary Turk Eximbank gives cover for such shipments against commercial/political risks since 1989. But, beneficiary is the confirming bank of $\mathrm{L} / \mathrm{C}$; not exporter regarding the product has been mentioned in this document. There is no any comprehensive academic study in the world about this subject.

The most comprehensive study about this subject is "Insurance of Confirmed Letter of Credit and Implementation of This Programme to Turk Eximbank" as one of the dissertations which are needed to become a specialist in Turk Eximbank. In that study, it is said that " $\mathrm{L} / \mathrm{C}$ confirmation insurance will be useful to serve Turk Eximbank's purposes in the context of facilitating exporters' presence in the new and risky markets and to strengthen their competitiveness in the current markets". 
Implementing authorities like Turk Eximbank are named as "Export Credit Agencies - ECA". Main "L/C confirmation insurance providers" are Federal Republic of Germany, DHAMAN (multinational), EXIMBANK SR (Slovakia), EXIAR (Russia), EFIC (Australia), EKN (Sweden), EKF (Denmark), FINNVERA (Finland), GIEK (Norway), ICIEC (multinational), OEKB (Austria), SACE (Italy), SERV (Switzerland), UKEF (United Kingdom) and US EXIM (USA) around the world.

Recent politic and economic turmoils force exporters to find safe areas even though issuing banks guarantee to pay $\mathrm{L} / \mathrm{C}$ amount to the exporter on condition that all terms in $\mathrm{L} / \mathrm{C}$ wording are met. Some cases could come into question such like issuing banks will not be able to fulfill their obligations due to the aforementioned risks (turmoils) or can have difficulties to transfer money because of the currency crisis. In these cases, $\mathrm{L} / \mathrm{C}$ confirmation insurance will help exporters to mitigate their risks.

In L/C confirmation insurance; banks operating in Turkey would be able to confirm letter of credits by means of this insurance type; maybe they wouldn't be able to confirm these letter of credits if there is no insurance for their confirmed letter of credits. Given the fact that private sector doesn't have an aim to incent exportation, but public sector has this aim; L/C confirmation insurance is in public sector's responsibilities mainly.

Results of the study could be summarized as follows:

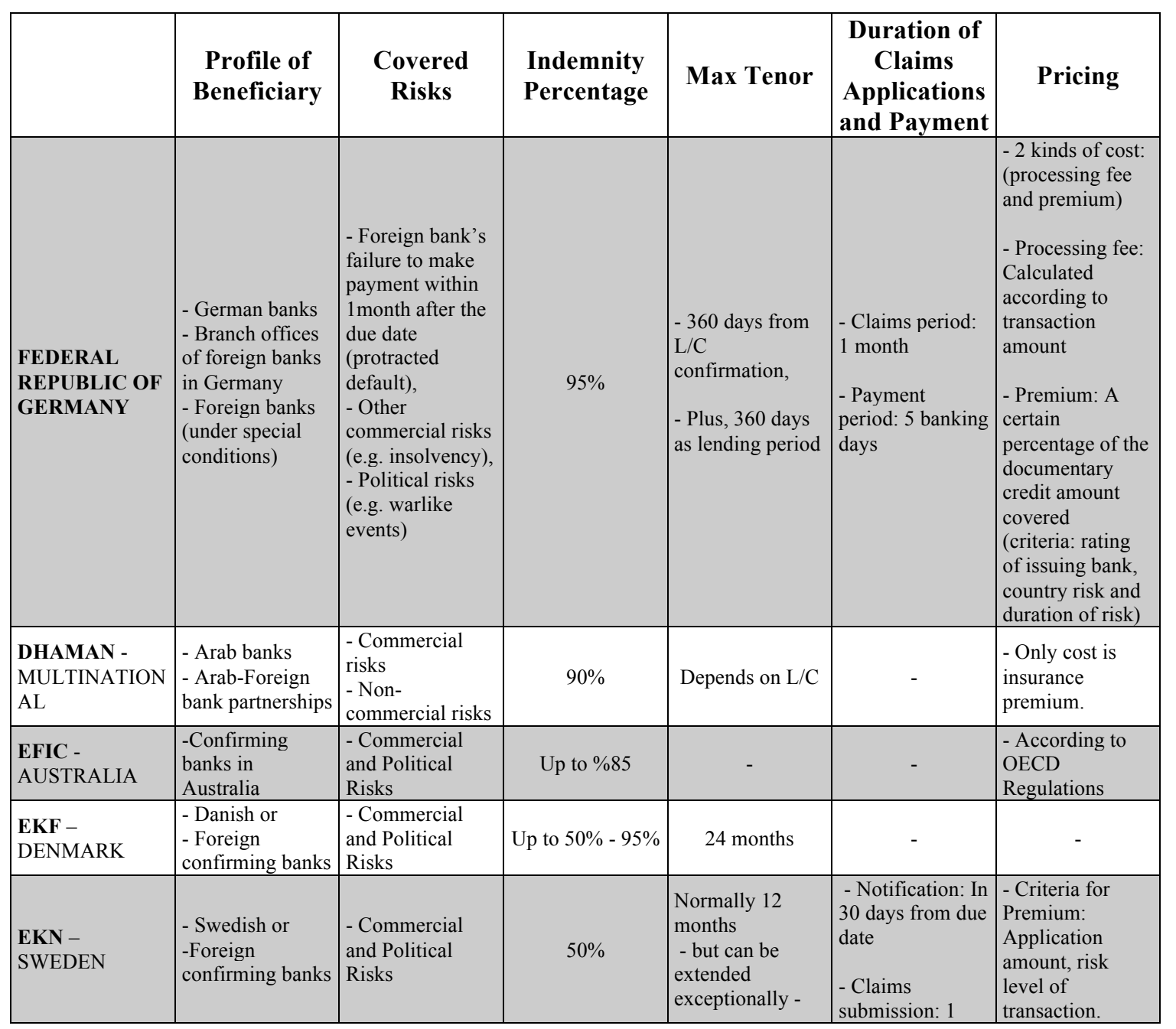




\begin{tabular}{|c|c|c|c|c|c|c|}
\hline & & & & & $\begin{array}{l}\text { year from due } \\
\text { date in written. }\end{array}$ & $\begin{array}{l}\text { Min premium: } \\
\text { 1500 Swedish } \\
\text { Kronor or its } \\
\text { equivalent }\end{array}$ \\
\hline & $\begin{array}{c}\text { Profile of } \\
\text { Beneficiary }\end{array}$ & $\begin{array}{c}\text { Covered } \\
\text { Risks }\end{array}$ & $\begin{array}{l}\text { Indemnity } \\
\text { Percentage }\end{array}$ & Max Tenor & $\begin{array}{c}\text { Duration of } \\
\text { Claims } \\
\text { Applications } \\
\text { and Payment }\end{array}$ & Pricing \\
\hline $\begin{array}{l}\text { EXIAR - } \\
\text { RUSSIA }\end{array}$ & $\begin{array}{l}\text {-Russian banks } \\
\text { or financial } \\
\text { institutions }\end{array}$ & $\begin{array}{l}\text { - Commercial } \\
\text { Risks (protracted } \\
\text { default, } \\
\text { bankruptcy etc.) } \\
\\
\text {-Political Risks } \\
\text { (Currency } \\
\text { Problems, War, } \\
\text { Force Majeure } \\
\text { etc.) }\end{array}$ & $\begin{array}{l}\text {-Political risks } \\
\text { (up to } 95 \% \text { ) } \\
\text {-Commercial } \\
\text { risks (up to } 85 \% \text { ) }\end{array}$ & Depends on $\mathrm{L} / \mathrm{C}$ & 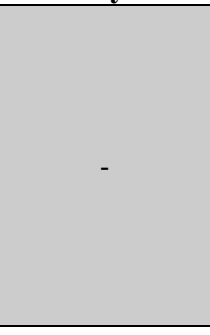 & $\begin{array}{l}\text { - Only cost is } \\
\text { insurance } \\
\text { premium. }\end{array}$ \\
\hline $\begin{array}{l}\text { EXIMBANKA } \\
\text { SR - } \\
\text { SLOVAKIA }\end{array}$ & $\begin{array}{l}\text {-L/C confirming } \\
\text { banks of Slovak } \\
\text { exporters }\end{array}$ & $\begin{array}{l}\text { - Commercial } \\
\text { and Political } \\
\text { Risks }\end{array}$ & up to $85 \%$ & 24 months & - & $\begin{array}{l}\text { Min premium: } \\
50 \% \text { of cost of } \\
\text { issuing bank's } \\
\text { for confirmation }\end{array}$ \\
\hline $\begin{array}{l}\text { FINNVERA - } \\
\text { FINLAND }\end{array}$ & $\begin{array}{l}\text { - Finnish or } \\
\text { - Banks on } \\
\text { abroad } \\
\text { (on condition } \\
\text { that L/C's } \\
\text { beneficiary will } \\
\text { be Finnish } \\
\text { exporter) }\end{array}$ & $\begin{array}{l}\text { - Commercial } \\
\text { and Political } \\
\text { Risks }\end{array}$ & $\begin{array}{l}\text { - In normal } \\
\text { coverage; } \\
\text { up to } 95 \% \text { for } \\
\text { commercial } \\
\text { risks, } \\
\text { up to } 100 \% \text { for } \\
\text { political risks, } \\
\text { - In risk sharing } \\
\text { model } 50 \%\end{array}$ & - & $\begin{array}{l}\text { Claims } \\
\text { submission: In } \\
60 \text { days after due } \\
\text { date } \\
\text { Claims Process: } \\
\text { FINNVERA will } \\
\text { conclude claims } \\
\text { process in } 30 \\
\text { days after } \\
\text { submission. }\end{array}$ & $\begin{array}{l}\text { - Criteria (in } \\
\text { normal } \\
\text { coverage): } \\
\text { Creditworthiness } \\
\text { of issuing bank } \\
\text { and its country, } \\
\text { validity pf L/C } \\
\text { and payment } \\
\text { conditions. } \\
\text { (In risk sharing } \\
\text { model) Based on } \\
\text { the confirmation } \\
\text { cost of issuing } \\
\text { bank } \\
\text { - For both model, } \\
\text { there is a } \\
\text { processing fee to } \\
\text { be paid extra. }\end{array}$ \\
\hline $\begin{array}{l}\text { GIEK - } \\
\text { NORWAY }\end{array}$ & $\begin{array}{lr}\text { - } & \text { Confirming } \\
\text { banks for the } \\
\text { goods } & \text { which } \\
\text { have } & \text { been } \\
\text { exported } & \text { from } \\
\text { Norway } & \end{array}$ & $\begin{array}{l}\text { - Commercial } \\
\text { and Political } \\
\text { Risks }\end{array}$ & up to $50 \%$ & - & - & $\begin{array}{l}\text { - Criteria for } \\
\text { premium: } \\
\text { Country of the } \\
\text { buyer and the } \\
\text { financial } \\
\text { situation of the } \\
\text { buyer }\end{array}$ \\
\hline $\begin{array}{l}\text { ICIEC - } \\
\text { MULTINATION } \\
\text { AL }\end{array}$ & $\begin{array}{l}\text { - } \\
\text { Banks\&Financial } \\
\text { Mnstitutions in the } \\
\text { Member States } \\
\text { - } \\
\text { Banks\&Financial } \\
\text { Institutions in } \\
\text { non-Members } \\
\text { countries; but } \\
\text { owned as 50\% } \\
\text { share or more by } \\
\text { the Islamic } \\
\text { Development } \\
\text { Bank or Member } \\
\text { countries } \\
\text { - } \\
\text { Banks\&Financial } \\
\text { Institutions } \\
\text { which have }\end{array}$ & $\begin{array}{l}\text { - Commercial } \\
\text { and Political } \\
\text { Risks }\end{array}$ & up to $90 \%$ & up to 7 years & - & - \\
\hline
\end{tabular}




\begin{tabular}{|c|c|c|c|c|c|c|}
\hline & \begin{tabular}{|l|} 
products \\
complying with \\
Shariah \\
\end{tabular} & & & & & \\
\hline & $\begin{array}{c}\text { Profile of } \\
\text { Beneficiary }\end{array}$ & $\begin{array}{l}\text { Covered } \\
\text { Risks }\end{array}$ & $\begin{array}{l}\text { Indemnity } \\
\text { Percentage }\end{array}$ & Max Tenor & $\begin{array}{c}\text { Duration of } \\
\text { Claims } \\
\text { Applications } \\
\text { and Payment }\end{array}$ & Pricing \\
\hline $\begin{array}{l}\text { OEKB - } \\
\text { AUSTRIA }\end{array}$ & -Banks in Austria & $\begin{array}{l}\text { - Commercial } \\
\text { and Political } \\
\text { Risks }\end{array}$ & up to $100 \%$ & up to 2 years & $\begin{array}{llll} & 0\end{array}$ & $\begin{array}{l}\text { - Processing fee: } \\
\text { between } 10 € \text { - } \\
720 € \\
\text {-Premium } \\
\text { (Depends on L/C } \\
\text { conditions) } \\
\end{array}$ \\
\hline SACE - ITALY & \begin{tabular}{|l|} 
- Confirming \\
banks for the \\
L/Cs issued on \\
behalf of Italian \\
exporters \\
\end{tabular} & $\begin{array}{l}\text { - Commercial } \\
\text { and Political } \\
\text { Risks } \\
\text { (up to } 5 \mathrm{~m} € \text { ) }\end{array}$ & - & up to 5 years & - & - \\
\hline $\begin{array}{l}\text { SERV - } \\
\text { SWITZERLAN } \\
\text { D }\end{array}$ & $\begin{array}{l}\text { - Confirming } \\
\text { Banks\&Financial } \\
\text { Institutions }\end{array}$ & $\begin{array}{l}\text { - Commercial } \\
\text { and Political } \\
\text { Risks } \\
\text { - Credit Risk } \\
\text { - Force Majeure }\end{array}$ & up to $95 \%$ & - & $\begin{array}{l}\text {-Claims } \\
\text { payment: In } 30 \\
\text { days after } \\
\text { submission. }\end{array}$ & $\begin{array}{l}\text { - Only cost is } \\
\text { insurance } \\
\text { premium }\end{array}$ \\
\hline $\begin{array}{l}\text { UKEF - } \\
\text { UNITED } \\
\text { KINGDOM }\end{array}$ & $\begin{array}{l}\text {-Banks in United } \\
\text { Kingdom }\end{array}$ & $\begin{array}{l}\text { - Commercial } \\
\text { and Political } \\
\text { Risks }\end{array}$ & up to $90 \%$ & up to 1 year & - & $\begin{array}{l}\text { - Premium: A } \\
\text { proportion of the } \\
\text { fee which UKEF } \\
\text { receives from } \\
\text { exporter for } \\
\text { confirming L/C } \\
\end{array}$ \\
\hline US EXIM - USA & $\begin{array}{l}\text { - Confirming } \\
\text { banks for the } \\
\text { American } \\
\text { products shipped } \\
\text { from USA or } \\
\text { rendering of } \\
\text { services by } \\
\text { American } \\
\text { personnel in any } \\
\text { part of the world } \\
\text { (goods or } \\
\text { services which } \\
\text { have less than } \\
50 \% \text { U.S. content } \\
\text { cannot be } \\
\text { covered - } \\
\text { defense products } \\
\text { are not subject to } \\
\text { this limitation). } \\
\end{array}$ & $\begin{array}{l}\text { - Commercial } \\
\text { and Political } \\
\text { Risks }\end{array}$ & $\begin{array}{l}\text { - Up to } 100 \% \text { for } \\
\text { sovereign } \\
\text { financial } \\
\text { institution, } \\
\text { - Up to } 95 \% \text { for } \\
\text { non-sovereign } \\
\text { financial } \\
\text { institution, } \\
\text { - Up to } 98 \% \text { for } \\
\text { approved } \\
\text { agricultural } \\
\text { commodities }\end{array}$ & up to 12 months & $\begin{array}{l}\text { - Claims } \\
\text { submission: Not } \\
\text { before than } 60 \\
\text { days, not later } \\
\text { than } 120 \text { days. - } \\
\text { A written } \\
\text { warning should } \\
\text { be sent to issuing } \\
\text { bank in } 30 \text { days } \\
\text { after due date. } \\
\text { - Claims } \\
\text { payment will be } \\
\text { realized in } 60 \\
\text { days after } \\
\text { receiving a } \\
\text { satisfactorily } \\
\text { completed proof } \\
\text { of loss. }\end{array}$ & $\begin{array}{l}\text {-Premiums are } \\
\text { calculated } \\
\text { according to the } \\
\text { specifications of } \\
\text { each application. } \\
\\
\text { - Advance } \\
\text { deposit of } \$ \\
2.000 \text { is paid to } \\
\text { set-up the policy. }\end{array}$ \\
\hline
\end{tabular}

Even though competitive atmosphere in international trade forces exporters to sell their products with cash against goods payment term, $\mathrm{L} / \mathrm{C}$ keeps its strong position as it is described as the life-blood of international trade. Hence, it is shown in the studies of WTO, IMF and BAFT (Bankers' Association for Finance and Trade) that one third of international trade is realized by the mediation of banks. It is forecasted that $12 \%-15 \%$ of international trade volume is realized by $\mathrm{L} / \mathrm{Cs}$.

Exporters who want to secure their receivables from importers against the default risk choose $\mathrm{L} / \mathrm{C}$ payment terms. But, as it is mentioned before in this study, even $\mathrm{L} / \mathrm{C}$ is not a totally risk-free payment term and it can be far from guarantee if economic and politic risks are growing in issuing bank's country. When such risk occur, there is a high possibility to see default risks due to deterioration of issuing bank's financial situation or political risks in the country which issuing banks is located. For such risks, L/C confirmation insurance is demanded from exporters or advising/confirming banks. 
$\mathrm{L} / \mathrm{C}$ usage in Turkey is nearly 11 billion USD in 2017 . It makes $7 \%$ of total export of Turkey. But we don't have statistical data regarding the (unrealized) potential export volume due to not having $\mathrm{L} / \mathrm{C}$ confirmation insurance. It is expected that $\mathrm{L} / \mathrm{C}$ confirmation insurance will come into prominence by providing guarantee to the confirming banks and exporters. However, discussions made with private sector representatives showed signs that there will be a reasonable demand for the product.

It is highly anticipated that $\mathrm{L} / \mathrm{C}$ confirmation insurance will increase the amount of export $\mathrm{L} / \mathrm{C}$ transactions in Turkey. Its effect on confirmation costs will be subject to banks' perspective on the product. Banks could not create any extra costs for exporters given the fact that they would not be able earn confirmation fees from them if there was no coverage for their L/Cs. In practice, it is also possible to create an additional cost for exporters by hiding it in confirmation fee.

Most likely, main demand will come from risky regions such as Africa, Middle East and Central Asian Turkic Republics. It will contribute the economic connection between Turkey and those countries and could act as a bridge between their financial institutions and ours.

$\mathrm{L} / \mathrm{C}$ credit confirmation insurance which is not offered from any company/institution in Turkey; but a very well-known product by other Export Credit Agencies around the world is expected to increase the volume of Turkey's exportation by starting to provide by Turkey's official export credit agency, Turk Eximbank. 